\title{
Nature and Economy in the Mining Region: Holistic Approach
}

\author{
Evgeny Zhernov ${ }^{1, *}$, Evgenia Nekhoda $^{2}$, and Dénes Peters ${ }^{3}$ \\ ${ }^{1}$ T.F. Gorbachev Kuzbass State Technical University, Department of Economics, 650000, Kemerovo, \\ Russian Federation \\ ${ }^{2}$ National Research Tomsk State University, Department of Strategic Management and Marketing, \\ 634050, Tomsk, Russian Federation \\ ${ }^{3}$ Budapest University of Technology and Economics, 1111 Müegyetem rakpart 1-6 Budapest, \\ Hungary
}

\begin{abstract}
The purpose of the study is to establish the relationship between the nature and the economy of the mining industry in the mining region in the context of the imminent depletion of the fuel and energy nonrenewable natural resources, which actualizes the research issue. The subject of the article is the qualitative relationship between nature and economy in the "nature - anthroposociety - economy" system. At the same time, the anthroposociety (man, society) is considered both as the creator of the economy, and as its condition along with nature. Much attention is paid to the world-view foundations of the issue - anthropocentrism and ecocentrism. In the study the issue of the relationship between nature and economy in the mining region is elaborated from the position of the holism methodology, which ensures the scientific novelty of the study. The scientific and practical significance of the study is in the establishment of the parity as a qualitative relationship between nature and economy in the mining region. This parity can be implemented to substantiate the transfer of the regional economic system of the Kemerovo region, an important mining region of Western Siberia, to a new resource-saving, high-tech and environmentally sound model of development.
\end{abstract}

\section{Introduction}

The purpose of the study is to establish the relationship between the nature and the economy of the mining industry in the mining region in the context of the imminent depletion of the fuel and energy nonrenewable natural resources. The scientific novelty of the study is in applying holism methodology to determine the relationship between nature and economy in the mining region. The scientific significance is in the establishment of the parity as a qualitative relationship between nature and economy in the mining region. The practical significance of the study is related to the possibilities of implementing the established parity of nature and economy in substantiating the transfer of the regional

*Corresponding author: zhee.eti@kuzstu.ru 
economic system of the Kemerovo region, an important mining region of Western Siberia, to a new resource-saving, high-tech and environmentally sound model of development. The goal is achieved through the scientific substantiation of a holistic approach to the relationship between the nature and the economy of the mining region, taking into account foreign experience in presenting the socio-economic role of nature in the economy.

\section{Materials and Methods}

The relationship between nature and economy has as its origin the relationship between nature and man, since economy is a part of human existence, its product. Two paradigms consider these relationships: anthropocentrism and ecocentrism. The general characteristics of the anthropocentric and ecocentric approaches to the relationship between man and nature are given in Table 1.

Table 1. Anthropocentric and ecocentric approaches to the relationship between man and nature.

\begin{tabular}{|l|l|l|}
\hline \multicolumn{1}{|c|}{ Characteristics } & \multicolumn{1}{c|}{ Anthropocentrism } & \multicolumn{1}{c|}{ Ecocentrism } \\
\hline $\begin{array}{l}\text { 1. Relationship rules } \\
\text { are established by }\end{array}$ & man & nature \\
\hline $\begin{array}{l}\text { 2. The support for the } \\
\text { rules - }\end{array}$ & mind, society, technology & natural forces \\
\hline $\begin{array}{l}\text { 3. Environmental } \\
\text { issues are } \\
\text { consequence of }\end{array}$ & $\begin{array}{l}\text { unsustainable management of the } \\
\text { economy, its excessive resource } \\
\text { intensity and waste generation }\end{array}$ & $\begin{array}{l}\text { anthropogenic exceeding of the } \\
\text { endurance threshold of the } \\
\text { biosphere, violation of its } \\
\text { regulatory functions }\end{array}$ \\
\hline $\begin{array}{l}\text { 4. Ways to resolve } \\
\text { problems - }\end{array}$ & $\begin{array}{l}\text { technological reorganization and } \\
\text { modernization of production }\end{array}$ & $\begin{array}{l}\text { not only technological, but also } \\
\text { ethical }\end{array}$ \\
\hline $\begin{array}{l}\text { 5. The center of } \\
\text { environmental } \\
\text { problems - }\end{array}$ & man, technology & $\begin{array}{l}\text { limits of sustainability of the } \\
\text { biosphere }\end{array}$ \\
\hline $\begin{array}{l}\text { 6. Nature - } \\
\text { 7. Proponents }\end{array}$ & $\begin{array}{l}\text { the object of "use" and the } \\
\text { property of man } \\
\text { politicians, economists, business }\end{array}$ & $\begin{array}{l}\text { system analysts, professional } \\
\text { environmentalists and ecologists, } \\
\text { eco-philosophers }\end{array}$ \\
\hline
\end{tabular}

From an economic point of view, proponents of anthropocentrism [1-5] declare nature to be the object of "use" and property of people (we note that in reality this concerns not all, but the elite). In this capacity, nature is reduced to an impersonal "environment". Therefore, the alleged ethical norms and rules of society do not cover the interaction with nature. In fact, the nature, a priori belonging to all people, including future generations, is subject to the exploitation relations of the elite part of society in its short-term interests. Nature is viewed from the perspective of "exploitatism".

Proponents of ecocentrism [6-10] consider the development of human society, including the economy, as part of the nature evolution. There are laws of economic limits and irreversibility, which cannot be changed by the laws of society by technological means. Ecocentrism is the ideology of environmental protection, which considers the preservation of wildlife as an independent value, regardless of any human criteria of benefit, and implying the priority of this value over the goals and needs of mankind.

In our opinion, the transition from anthropocentrism to ecocentrism is caused by the awareness of mankind of the fact that the scale of its economic activity exceeded the anthropogenic limits of nature, it is close to the depletion of natural resources, and this requires consideration of ecology, including at the corporate level [11]. 
Anthropocentrism and ecocentrism are also the main models of the ecological development of mankind. The concept of eco-development as an environmentally-oriented socio-economic development, in which the growth of human well-being is not accompanied by a deterioration of the habitat and the degradation of natural systems, was first formulated by M. Strong [12]. The basis of the principle of eco-development is an anthropogenic approach to the evolutionary process, which, in turn, relies on understanding the role of man in the world not as a "parasite on the body of nature" [13], but as a creature organically included in the biosphere. Hence, the principles of eco-development imply the achievement of the unity of man and nature.

Thus, the world-view becomes ecological in essence, naturally containing human activity. The concept of eco-development, being broader than "nature conservation", implies saving of humanity due to the reasonableness of Homo sapiens (human creator) both outside and inside mankind, and the absence of danger for man himself from the technosphere - his product. So, eco-development is a form of sustainable socio-economic development of man and society in the environmental preservation restrictions of a specific historical period of time. In our opinion, such a definition corresponds to the "nature anthroposociety - economy" system. In this system, it is clear that the principles of anthropocentrism cannot be realized without implementing the principles of ecocentrism.

According to the considered paradigms, in the mining region the economy of the mining industry is a part of nature in ecocentrism, and in anthropocentrism nature is a part of the economy of the mining industry. Based on the principle of preserving the ecological capacity of a territory, at the regional level, the economy of the mining complex should be included in the nature's economy of the region: subject to it and not go beyond it.

\section{Results and Discussion}

The scientific substantiation of establishing the relationship between nature and the economy in a coal-mining region, in our opinion, includes: 1) finding out the essence of coal as a nonrenewable natural resource and as a product; 2) determining the role of nature in the mining industry; 3 ) the formulation of the main difference between the nature and economy of the mining industry.

A man, having discovered coal in nature in a form that was not intended for him, managed to adapt this natural substance for consumption in everyday life and in production. At a certain stage of development, industrial for coal, the availability of a natural resource gives all the benefits to people living in a given territory. Coal mining itself is not an actual production, it is only a preparation for it. Nature has given only preliminary properties of coal as a future product. Coal as a product is present in nature in itself, in the so-called folded form.

It is known that to produce is to make a product with the help of instruments of labor. And this is done only by an economic man (Homo economicus), initially free from the influence of ethics [14], and only being in a society created by the improvement of instruments of labor. For us in this article it is important the philosophical position that nature does not produce and does not consume, therefore, there are no products in nature. Only man produces a product and consumes it. And this is the main difference between nature and economy created by a social man (Homo sociologicus), subject to the influence of ethics, in the process of exchanging products. Not extracted coal is not a product of nature, but a product found in nature in itself.

Nature and man with the economy as his product together form a single whole, a kind of mutually reproducing reality of a single one. In our opinion, this unity is the objective possibility of a holistic approach to the relationship between nature and economics. A man as a form of development of this single whole, separated from nature, must "remove" 
nature, that is, destroy and preserve it at the same time. With regard to the "coal" product, such a removal of nature means that for a man the product replaces nature with itself, while at the same time retaining its substance in itself. A coal product is not coal, given by nature; it is coal that is extracted. But coal as a matter of nature is unconditionally preserved in the coal mined. In this sense, the coal mined destroyed the remainder of the coal as a natural substance, while at the same time retaining it as a subordinate side. This is the removal of the nature by the product - coal mined. The latter, as a fragment of nature, remains connected with the rest nature not removed yet. It is nature that is the main condition for its production and consumption. It means that without nature, a mining economy is impossible in principle.

Nature always, directly or indirectly, has a medium-term and long-term impact on human economic activity. In the process of creating any product, a man is in natural conditions. In other words, creating a product, a man produces in natural conditions. But at the same time, in accordance with his short-term needs, he also enters into institutional relations with other economic actors from various social groups. So, he produces in conditions ordered by society - social conditions. From the standpoint of ecology, both natural and social conditions affect the level of development of production in the same way. An example of Kuzbass shows the following: natural conditions provide the richest natural resources for economic growth in the region. However, social conditions in the form of the absence of norms and rules in the economic system that ensure the reproduction of resources in the long term make this growth problematic. Thus, the combination of social and natural conditions of production and reproduction of coal as a human product constitutes the environment of the coal mining industry and its economy.

Production of a product is carried out not only under certain conditions and with the availability of resources, but also with the participation of factors of production that form and fill an economic space. In the context of the research issue one should distinguish between natural and ecological factors of production. By natural factor we mean the forces of nature and material substances having a natural basis that are used by man in the process of producing products in order to meet his immediate needs. This factor directly affects the production process in the mining industry: the qualitative and quantitative properties of the product depend on it. The environmental factor is more associated with the long-term impact of economic activity of society on nature.

The relations of nature and economy of the mining industry in their present form have obviously stalled. This is clearly seen in the example of Kuzbass. Man has replaced the smallest particle of natural substance with the product (coal mined), and together with the economy of the mining industry he falls into the trap of his relationship with nature, more precisely his attitude to nature. And here such remark is pertinent. Since nature, unlike man, who is the creator of the economy, has no spirit, it cannot have an attitude to the economy. Consequently, it is incorrect to discuss the relationship between the economy and nature, as is done in anthropo- and ecocentrism. But we can and should talk about the problem of their correlation in the system "nature - anthroposociety (man, society) - economy (a part of society, product of man)". Moreover, in the context of the interaction of the human economy and the nature economy, it is necessary to consider not only the macroeconomy, but also the mesoeconomy.

Returning to the question of replacing nature with a product, we believe that its essence is expressed by Hegel's "bad infinity". The result of this substitution, not immediately realized by man, is the elimination of the element "nature" and, accordingly, of the elements "anthroposociety" and "economy" from an ecologically equilibrium state. Coalbased industry requires new coal mining. It destroys the nature of Kuzbass. Coal should not be barbarously mined in the area of its occurrence, and then moved to areas of processing and consumption, but it is necessary to make the predominant nature-like technologies of 
coal mining and processing on site. Otherwise, in the near future, Kuzbass will turn into a deserted zone of industrial coal mining by robots, since man cannot exist in the natural environment depleted by him, unless, of course, he changes the environment so that it remains habitable. But the problem is that this change at the current level of technology development will occur through the production and consumption of the next product, that is, by replacing nature with such a human product as the technosphere, which has spread today to the whole way of life of people.

The philosophy of technology development is designed to give man the opportunity to determine the consequences of replacing nature with a product, at least theoretically. This philosophy should form the conceptual foundations of the economy in deed and not in words. It is unlikely that man will be able to turn nature into a product completely. The development and creation of nature-like technologies and products, or, better, technologies and products that are organically consistent with nature, seem more realistic and correct. Only then the "bad infinity" will be interrupted, the process of removing nature with the product will end: nature will be preserved and not destroyed. The product will become nature, and not second nature, replacing the first one, and not nature which exists in parallel, but the only one. Man will return to nature at a new level of his development, not humanizing it, that is, transforming in accordance with his current ideas about anthroposocial being, but finally adopting its laws as his own.

Table 2. Characteristics of the three states of the relationship between nature and man with his product.

\begin{tabular}{|c|c|c|c|}
\hline Characteristics & $\begin{array}{l}\text { The priority of nature } \\
\text { over man and his product }\end{array}$ & $\begin{array}{l}\text { The priority of man } \\
\text { and his product over } \\
\text { nature }\end{array}$ & $\begin{array}{c}\text { Parity of } \\
\text { nature and } \\
\text { man with his } \\
\text { product }\end{array}$ \\
\hline $\begin{array}{l}\text { 1. Conditionality of } \\
\text { priority: }\end{array}$ & $\begin{array}{l}\text { new initial isolation of a product } \\
\text { from nature as the simplest } \\
\text { substance, but qualitatively } \\
\text { different from it }\end{array}$ & $\begin{array}{l}\text { connected to the division } \\
\text { of labor }\end{array}$ & 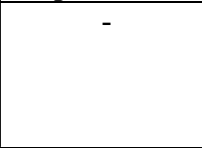 \\
\hline 2. Product & $\begin{array}{l}\text { remains almost natural, yet } \\
\text { accidental substance. It is a } \\
\text { direct mutual transition of } \\
\text { production and consumption. }\end{array}$ & $\begin{array}{l}\text { - the result of the } \\
\text { stability and reliability } \\
\text { of the processes of } \\
\text { production and } \\
\text { consumption. Anti- } \\
\text { natural substance: } \\
\text { pollutes nature, } \\
\text { oppresses man }\end{array}$ & $\begin{array}{l}\text { man makes it } \\
\text { nature }\end{array}$ \\
\hline $\begin{array}{l}\text { 3. Man, society } \\
\text { (anthroposociety): }\end{array}$ & $\begin{array}{l}\text { man makes the first attempts to } \\
\text { produce and consume. } \\
\text { Everything produced is } \\
\text { produced by himself and for } \\
\text { himself, therefore he controls } \\
\text { the process. Becomes the owner } \\
\text { of the product. Remains a slave } \\
\text { of nature }\end{array}$ & $\begin{array}{l}\text { man depends on nature } \\
\text { in a new way. Making } \\
\text { and consuming not the } \\
\text { whole product, man does } \\
\text { not control the whole } \\
\text { process of production } \\
\text { and consumption. } \\
\text { Society does it. The man } \\
\text { is the slave of the } \\
\text { product }\end{array}$ & $\begin{array}{l}\text { man together } \\
\text { with nature is } \\
\text { the creator of } \\
\text { everything and } \\
\text { himself }\end{array}$ \\
\hline 4. Economy & appropriative economy & $\begin{array}{l}\text { industrial economy, not } \\
\text { subject to man } \\
\text { (producing economy) }\end{array}$ & $\begin{array}{l}\text { economy } \\
\text { based on } \\
\text { human } \\
\text { knowledge }\end{array}$ \\
\hline 5. Nature & $\begin{array}{l}\text { is not removed, since the being } \\
\text { of the product is completely }\end{array}$ & $\begin{array}{l}\text { not removed, remaining } \\
\text { nature is disturbed and }\end{array}$ & $\begin{array}{l}\text { man makes it a } \\
\text { product }\end{array}$ \\
\hline
\end{tabular}




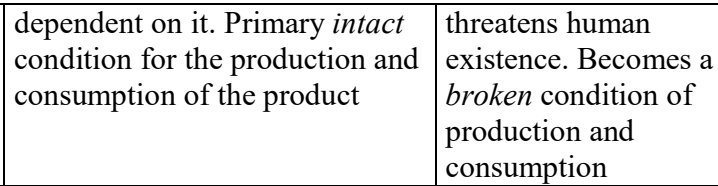

Thus, we do not take the side of ecocentrism, which professes the power of nature over man and his product, nor the side of anthropocentrism, which recognizes the power of man and his product over nature. The result of the study is the assumption of the interpenetration (inseparability) of nature and man with his product (Table 2).

As shown in Table 2, nature becomes a new meaning for man, and man himself becomes one of the forces of nature, simultaneously changing each of them and directly dependent on them. Everything in natural systems is strongly interconnected: man is in nature, as in his own body, and not in the environment, is connected with it very closely, is not alienated from it, like the spirit from the body. As Homo sapiens, man feels one with nature. The third state is based on the principle of the identity of nature and man: for man, to be means to be in nature. In applying this principle, we see the essence of the sought holistic approach to the relationship between nature and economy in the mining region.

Holism considers the system only as a whole. If the "nature - anthroposociety economy" system does not apply the principle of holism, the anti-natural activity of economic actors makes the existence of the system impossible. Therefore, we believe that the relationship between nature and economy can be only parity.

The methodology of holism (integrity) gives us the possibility to develop a holistic approach to the relationship between nature and economy in the mining region, considering them in inseparable unity. In this case, it refers to the integrity of nature and economy for two reasons: 1) the anthroposociety (man and society) - the creators of the economy - are themselves part of nature; 2) without the resources of nature there can be no mining industry with its economy. Thus, nature and economy in the mining region are interrelated equal parts of a whole.

\section{Conclusion}

The application of the holism methodology allowed us to formulate the basic theoretical position for elaborating the issue of the relationship between nature and economy in the mining region in the context of the depletion of the fuel and energy nonrenewable natural resources. The establishment of parity between nature and economy in the mining region seems to us as such a basis. It is shown by the example of the mining industry of the Kemerovo region, an important mining region of Western Siberia.

In Kuzbass, the implementation of the idea of parity between nature and economy as a single entity will allow the regional economic system to be transferred to a new resourcesaving and environmentally sound, ethical model of development.

The research is done under the financial support of the Russian Foundation for Basic Research, Research Project № 18-010-00340 "Business Models of Companies as the Basis for the Formation of Common Values and Social Capital".

\section{References}

1. P. Teilhard de Chardin, Man's place in nature: the human zoological group (Collins, London, 1966)

2. L. White, Jr., Science, 155, 1203 (1967)

3. A. Peccei, The human quality (Pergamon Press, New York, 1977) 
4. J.L. Simon, The ultimate resource (Princeton University Press, Princeton, 1981)

5. C.R. McConnell, S.L. Brue, S.M. Flynn, Economics: principles, problems, and policies (McGraw-Hill Education, New York, 2018)

6. A. Leopold, A Sand County almanac and sketches here and there (Oxford University Press, London, 1968)

7. R. Costanza, J.C. Cumberland, H.E. Daly, R. Goodland, R. Norgaard, An Introduction to Ecological Economics (St. Lucie Press, Boca Raton, 1997).

8. T. Regan, Defending animal rights (University of Illinois Press, Urbana, 2001)

9. P. Singer, The life you can save: acting now to end world poverty (Random House, New York, 2009)

10. A. Naess, Ecology of wisdom (Penguin Books, London, 2016)

11. M.E. Porter, M.R. Kramer, HBR, 1-2, 62 (2011)

12. M.F. Strong, Where on earth are we going (Texere, London, 2000)

13. A. Næss, Hvor kommer virkeliheten fra? Samtaler med Arne Noess (Kagge Forlag AS, Oslo, 2000)

14. K. Brunner, W.H. Meckling, JMCB, 9:1, 70 (1977) 